employees which might be detrimental to the nation's economy. The growing acceptance in negotiating and arbitration procedures of the principle of comparability and the application of 'fair comparisons' formulæ largely solved the unions' difficulty. However, this was called into question by the Government's insistence that Britain's economic difficulties would not be solved unless wage increases were restricted to what the country could afford, and that wages must not increase on average faster than the average increase in national productivity. Pointing out that the public sector could play an important part in a national wages policy, $\mathrm{Mr}$. Donoughue notes also that three specific questions will arise: how to ensure that public servants do not suffer a pay disadvantage compared with production workers; the role, if any, of arbitration; and the fixing of wages for loss-making public industries, such as the railways.

\section{The Supply of Science Teachers}

Is replying to a debate on science and mathematics teachers in the House of Commons on December 21, opened by Mr. A. Skeffington, the Parliamentary Secre. tary to the Ministry of Education, Mr. C. Chataway, said that in March 1961 there were 7,321 mathematics graduates and 12,734 science graduates in grant-aided schools and establishments, increases of nearly 10 per cent and nearly 15 per cent, respectively, in two years; in the maintained secondary schools the figures were 5,077 and 8,528 , increases of 7.8 per cent and 13.2 per cent, respectively. The numbers of mathematics and science graduates entering university departments of education to train as teachers had risen from 715 in 1957-58 to 965 in 1961-62 and 1,110 in 1962-63. While the growth in numbers entering the schools had kept pace with the general increase in the graduate teaching force, men teachers had been leaving the schools more rapidly than normally expected, in consequence of the ending of deferment under National Service, and further education and the training colleges had been gradually increasing their demands for mathematics and science graduates as part of their expansion programme. Physics teachers were far harder to come by than teachers of biology, and the general situation for girls was worse than for boys. The Ministry's Curriculum Study Group had embarked on a study of typical curricula patterns for schools of different types in relation to the demand and supply of teachers of particular subjects. Closer links were being formed with university appointments officers and a small steering committee had been established on the supply of mathematics teachers, bringing together schools, universities and the Ministry. The three-year course had given the training colleges the opportunity to broaden and deepen the training given to non-graduate teachers of science and mathematics. For mathematics there were about 240 lecturers and another 60 were teaching mathematics part-time or in combination with another subject. Science lecturers were limited to about 45 colleges. An encouraging expansion of teaching on television was proceeding and agreement had been reached between the British Broad. casting Corporation, the Independent Television Authority and the Postmaster-General on adult education and the expansion of the time allocated to it.

\section{Standardization of International Non-Proprietary} Names for Drugs

THE World Health Organization has long been conscious of the need for standardizing non-proprietary names for drugs and seeking to gain their international recognition. In far too many cases the proposed international non-proprietary name (for example, thalidomide) has not appeared on the packaye in addition to the proprietary name, and this has complicated the problem of preventing, if necessary, any further use of the drug. Since 1953, lists have been published at intervals in the WHO Chronicle of proposed international non- proprietary names, and their adoption by national authorities for use in official texts, regulations, national pharmacopoias and other collections of specifications is becoming increasingly common. The first eleven lists of proposed international non-proprietary names have now been collected together under the title of International Non-proprietary Names for Pharmaceutical Preparations : Cumulative List 1962, giving the non-proprietary names in Latin and English, accompanied by the ehemical names or descriptions in English (Pp. 52. Geneva: World Health Organization; London: H.M.S.O., 1962. 3 Swiss francs; $5 s . ; 1$ dollar). The procedure for the selection of international non-proprietary names and the general principles for devising such names are appended at the end of the list. This publication should be of considerable assistance to national control authorities and pharmaceutical manufacturers, as well as to pharmacists, doctors and editors of scientific literature.

\section{The O.E.C.D. Observer}

The first issue of The O.E.C.D. Observer (November 15, 1962), published bi-monthly by the Organization for Economic Co-operation and Development, includes an article by $T$. Kristensen, the secretary-general, deseribing the purpose of this new periodical and an article by Prof. I. Svennilson on the role of research and education in the growth of an economy. The issue contains an article by C. Rehn on manpower, adaptability and economic growth, and some account of the Organization's structure for aiding development, including technical and educational assistance to newly developing countries. Also presented is a supplement which describes the aims, structure and work of the Organization, including an organization chart which indicates the place of the Committees of Scientific Research, Scientific and Technical Personnel, the Directorates for Scientific Affairs and for Manpower and Social Affairs, and the European Nuclear Energy Agency. Copies of The O.E.C.D. Observer are obtainable from O.E.C.D. Information Service, Château de la Muette, Paris $16^{\mathrm{e}}$.

\section{The Geology of Edinburgh}

Just more than a contury ago, the Geological Survey of Scotland published the first edition of its memoir on The Geology of the Neighbourhood of Edinburgh. Fifty years later a second edition appeared, and now after another half-century a third edition has been published (Pp. xii $+159+4$ plates. Edinburgh: H.M.S.O., 1962. 35s. net). Probably no city in the world has made as great a contribution to geological thought and theory as has the Scottish capital, and it is a measure of the continuation of this tradition that this latest work, compiled by Dr. G. H. Mitchell and Mr. W. Mykura, is almost wholly concerned with information acquired by the Geological Survey since 1910. Not a mention of Hutton and his associates is to be found in its pages! In one respect alone does the new memoir compare unfavourably with its predecessors: although half the length of the 1910 edition (which had a coloured map), it is nearly five times its price. Not long ago the Edinburgh Geological Society sponsored a model guide for geological tourists (Edinburgh Geology: An Excursion Guide. Pp. xv $+222+$ 8 plates: Edinburgh, Oliver and Boyd Ltd., 1960. 12s. $6 d$. net); and the juxtaposition of these two new books brings little credit to the costing methods of H.M.S.O., which result in the publications of the British Geological Survey being more expensive than those of most comparable official organizations overseas.

\section{Research on Food Preservation in Australia, 1961-62}

READERs of Food Preservation Quarterly will doubtloss be aware of the stream of useful work which has emanated from the Food Preservation Division of the Commonwealth Scientific and Industrial Research Organization, 